\title{
Europeanization in the Making: Perceptions of the Economic Effects of European Integration in Romania
}

\author{
Florența Toader and Loredana Radu
}

\section{Introduction}

The topic regarding public opinion towards the European Union has generated extensive debate in recent years. Starting with political leaders and official representatives of the EU and continuing with scholars and the media, the topic has garnered several points of view and explanations regarding the triggers that keep the public attached to the European project. The turning point for these discussions was firstly marked by the economic crisis in 2009, which brought a change of heart among Europeans regarding the capacity of the Union to adequately respond to the needs of citizens in different member states in times of economic turbulence. With the crisis came an increased distrust in the EU and a wave of criticism that evolved with the passing of the years.

Recent events such as the rising extremist and anti-European parties all over Europe and the spread of populist rhetoric are only a few examples of the type of challenges that today's EU is facing in order to maintain its existence. According to the Standard Eurobarometer published August 2017, more than four in ten Europeans, representing $42 \%$ of the total sample, trust the European Union. Comparing this percentage with the results of a Eurobarometer published in the autumn of 2015 , trust in the EU has increased by $10 \%$. However, the crisis that the EU is facing is far from over, and the topic of shifting attitudes towards the EU still stands. The same Eurobarometer (August 2017) shows that Eastern-European states such as

This chapter has been prepared with financial support granted in the project "State of the Nation. Designing an innovative instrument for evidence-based policy-making" (SIPOCA 11, MySMIS 118305), which is co-financed by the European Social Fund through the Operational Programme Administrative Capacity 2014-2020.

F. Toader $(\bowtie) \cdot$ L. Radu $(\bowtie)$

National University of Political Studies and Public Administration, Bucharest, Romania e-mail: florenta.toader@comunicare.ro; loredana.radu@ comunicare.ro 
Lithuania (65\%), Romania (57\%) and Bulgaria (54\%) maintain a strong Eurooptimistic orientation. In Romania's case, it is still challenging to explain the pro-European attitude considering that the economic benefits post-integration do not support such a high level of backing for the EU. In this sense, Romanians perceive the economic situation as the third most important concern of the Union (Eurobarometer, August 2017). Still, 67\% of the Romanian respondents are optimistic regarding the future of the EU.

In this context, the following contribution attempts to explain Romanians' trust in the EU despite little economic progress after the European integration and low salience of European issues in the Romanian public space. The chapter builds on previous qualitative research conducted by Fomina and Radu (2017), which assesses public attitudes towards the EU among students from Poland and Romania. The present study, however, focuses exclusively on the Romanian realm and has a quantitative approach, using data collected through a national omnibus survey conducted in September 2017 and secondary data analysis concerning the economic effects of European integration.

\section{The Utilitarian Approach to EU Support}

When assessing the different predictors of trust in the EU, scholars usually differentiate between economic interests, group identities, and political rhetoric. According to de Vreese and his collaborators (2008), support towards European integration is given not only by utilitarian predictors (economic interests), also called hard predictors, but also by soft predictors such as the degree of identification with one's national identity or the attitude towards migrants. Continuing this idea, Boomgaarden et al. (2011) identify specific and diffuse models of support towards the EU. Specific support is based on concrete policy outcomes or performance while diffuse support derives from the evaluation of the core values of the Union.

According to the utilitarian model, the aspects that influence attitudes towards the EU are based on calculi regarding the benefits of integration over the national economy (Hooghe and Marks 2004). In other words, people tend to have more trust in Europe in times of economic growth and attribute their own country's wellbeing to European integration. The level of trust in the European project decreases when the EU's economic performance is weaker. As a result, this type of support is dependent on short-term results (Boomgaarden et al. 2011) and on subjective evaluations regarding the future of the economy (De Vreese et al. 2008; Bârgăoanu et al. 2013). When any perceived benefits are low or challenged by crisis situations, trust in the EU drops.

Given its subjective matter, the utilitarian view of the benefits of EU integration can manifest itself both at a macro and micro level (Fomina and Radu 2017). At a macroeconomic level, attitudes towards the EU are shaped by the increase in the 
level of international trade (Eichenberg and Dalton 1993). At the micro level, people shape their attitude towards the European project based on the impact integration had on their lives from an economic point of view. Authors such as Anderson (1998) proved that European citizens use their own country's performance when evaluating the EU. At the same time, assessments of the national and supranational performance of government are connected and influence each other (Harteveld et al. 2013). Therefore, the levels of satisfaction regarding the functioning of the national institutions and democracy together influence how citizens appraise EU democracy.

Still, not all citizens evaluate the economic impact of integration over their lives in the same manner. As studies show (Anderson and Kaltenthaler 1996; Gabel 1998), citizens with larger human capital usually have more opportunities to benefit from European integration. As a result, citizens that were already doing well economically tend to have more trust in the EU. Another important factor is the region of residence. As Gabel (1998) notes, residents of frontier countries of the EU are usually more Euro-optimistic as they draw more benefits from the free circulation of goods and people across the EU. This theory is usually used to explain Eastern-European countries' trust in the EU. According to this view, Eastern-European countries with weaker democracies and economies benefit economically from European integration, hence their support for integration. At a macroeconomic level, attitudes towards the EU are shaped by the increase in the level of trade (Eichenberg and Dalton 1993).

However, the utilitarian view regarding public support towards the EU has several shortcomings that need to be addressed. Firstly, according to the synthesis made by Fomina and Radu (2017), the average citizen does not have the capacity to accurately assess the effects of European integration on a personal level. This ability is even more limited when talking of a precise evaluation of changes in foreign trade. This assumption however overlooks the lack of knowledge about the EU, which citizens from different member states experience differently. For instance, in Romania the inclusion of EU issues on the public agenda is limited, therefore no amount of citizen evaluation of the EU performance, based on national performance, can explain the trust Romanians still have in the EU. This aspect is once more important in the context in which Romanians perceive the economic situation of their country as a main source of concern (Standard Eurobarometer, August 2017), and the low economic growth after the integration backs up this concern. It has been proven therefore that the utilitarian view has several limitations. While this approach is useful to explain "the emergence of intra-EU cleavages" between "the rich Westerners and the poor Easterners" (Fomina and Radu 2017), it is mostly based on artificial discrepancies between countries with strong economies and developing European countries. Moreover, utilitarian thinking shows its limits in specific cases such as Poland or Hungary - two European countries that greatly benefitted from European funds but in recent years have developed a strong Eurosceptic attitude. Moreover, studies have demonstrated the limits of the neoliberal view according to which a citizen is exclusively a homo economicus, concerned solely with the economic aspects of their life. 


\section{Soft Predictors of EU Support}

According to de Vreese and his collaborators (2008), besides hard predictors of EU support (based on economic calculi), soft predictors should also be taken into consideration. The same idea is supported by scholars such as Boomgaarden et al. (2011), De Vries (2010), and De Vries and Hobolt (2012). According to these authors, evoking strong emotions is a good tactic to mobilize voters around issues related to EU integration. From this point of view, one can include in the category of soft predictors of attitudes towards the EU the symbolic meaning of EU membership. This type of reasoning emerged because of the changes the European project experienced years after the Maastricht treaty signing and the adoption of the expansion policy of the Union. More countries were dissatisfied with the integration of less developed states, which can shake the economic balance of the EU. Another consequence of these transformations was that more states started to adopt a type of rhetoric that militated towards the conservation of the integrity of the national state and its culture. This type of reaction can be explained through the fact that with the passing of the years, the EU has drifted away from its initial purpose-economic cooperation. Based on this theory, Hooghe and Marks (2004, 2005) noted that national identity-related aspects are central to the process of formation of attitudes towards the EU.

Studies on Euroscepticism place at the core of this view the idea of indivisibility of the nation-state. According to this view, European integration is illegitimate since it transfers political power from the national state to a different political entity. Without EU interference, states would be perfectly able to deal independently with the different challenges they face-the economic crisis, the immigrant crisis, etc. According to Fomina and Radu (2017), these arguments against EU integration can be ultimately reduced to the averseness of different national states towards multilevel governance. At this level, national identity and values are threatened by the fact that the EU as a supranational organism infuses foreign values and norms. Still, we argue that the symbolic meaning of EU membership can also lead to positive attitudes towards the Union. In this case, citizens' evaluation of EU values as being desirable compared to the policies conducted by internal government can be a strong predictor of Euro-optimistic attitudes.

At the same time, political cues coming from political parties also play a role in the process of attitude formation towards EU integration. Recent studies such as that conducted by Rohrschneider and Whitefield (2016) have proven that Eurosceptic attitudes are also shaped by the orientation of mainstream and extremist parties towards the EU. According to these authors, in economically consolidated states, mainstream parties, especially those representing the right-wing, maintain a pro-European discourse as they were involved in the building of the European project. Adopting a different approach might foster imagological and credibility problems. At the opposite side of the political spectrum, extremist parties tend to adopt a Eurosceptic rhetoric, drawing on the shortcomings of European integration. This tendency is mostly present in Western Europe, where states have been involved 
since the beginning in the process of building the EU. Moreover, parties that evolved there after 2008-2009 are even more Eurosceptic as they were created specially to criticize and delegitimize the EU. However, this is not the case for parties in Central and Eastern Europe. These parties still have a pro-integration rhetoric as they are concerned with other political issues, and the imagological investment in this topic is lower than in the West.

The last factors of EU attitude formation discussed above-concerns related to national state integrity, national identity, and political cues-are interconnected. National identity does not necessarily exclude European identity, even though the latter is usually less consolidated. The type of national identity, however, may impact the way citizens evaluate issues concerning the EU (Hooghe and Marks 2005; Luedtke 2005; Bruter 2008; Van Klingeren et al. 2013). According to De Vries and Edwards (2009), countries have either inclusive or exclusive identities. Countries with inclusive identities tend to be more Euro-optimistic while the ones with an exclusive national identity are more prone to reject the European values. This observation is important because citizens coming from the latter categories of countries are more exposed to the influence of political framing and cueing and, in the end, can perceive European integration as a threat to national identity. They are also more vulnerable to Eurosceptic propaganda (Fomina and Radu 2017). Moreover, studies (Hooghe and Marks 2005) show that in national contexts where elites share consent over European integration, national and European identities are complementary. This is not the case for states where elites disagree over integration. In the latter contexts, national identity can foster Euroscepticism. As Fomina and Radu (2017) note, "Since the European identity is still much weaker than the national identities, many citizens may strongly believe that decisions should be taken on the national rather than the European level, not because of efficiency concerns, but because it reflects the collective will of the group they identify stronger or exclusively with". This approach goes beyond the initial goal of the EU, which was economic cooperation, and focuses on aspects such as the preservation of culture and traditions.

Our assumption in this chapter is that Romanians' attitudes towards the EU are shaped mainly by soft predictors such as the meaning of EU integration and identityrelated issues. For example, the pro-European attitudes in a country where Europeanization is still "in the making", 10 years after integration, are the perceived desirability of European values versus other geopolitical options and the disappointment with the national political institutions. While most of the studies aiming to measure patterns of EU support have been conducted in rather stable times, the present research sheds light on this topic in a time characterized by several ongoing EU crises (e.g. euro crisis, sovereign debt crisis, refugee crisis, Brexit). 


\section{Methodology}

The goal of the present chapter is to observe and explain patterns of EU support in Romania, a country that continues to keep its pro-European orientation despite little economic progress after the European integration and low salience of European issues in the Romanian public space. We challenge one of the most frequent approaches towards EU support: the utilitarian theory, according to which Eastern-European citizens' perceptions of the EU are shaped by the economic benefits brought by integration. In this regard, the following research objectives and hypotheses were set:

Ob.1 To investigate the impact of EU integration on Romania's economic performance based on the following indicators-GDP and GDP per capita, evolution of public debt, and the absorption of EU funds;

H1. The evolution of the Romanian GDP per capita / public debt / absorption of EU funds does not support the utilitarian view of EU support in Romania;

Ob.2 To investigate Romanian citizens' perceptions of the economic development of the country in the CEE region;

H2. Romanian citizens' evaluation of national economic performance is lower compared to other EU member states;

H3. Romanian citizens' evaluation of personal economic performance is lower compared to other CEE member states;

Ob.3 To investigate Romanian citizens' trust in the local political institutions as compared to the EU;

H4. Romanians tend to trust the European Union more than they trust internal political institutions;

Ob.4 To investigate Romanian citizens' perception of the impact EU funds has on the economic growth of the country;

H5. Romanian citizens perceive EU funds as having a positive impact on the national economy;

Ob. 5 To investigate Romanian citizens' personal evaluation of their life quality and its correlation with EU support.

H6. The better Romanians evaluate their life satisfaction, the greater is their trust in the EU.

In order to meet the research objectives, our study is structured in two parts. The first step of the study is to analyze hard data on the economic effects of European integration to verify if hard data regarding the state of the Romanian economy support the utilitarian thesis. The data presented in this contribution, ranging from 1987 to 2016, have been collected from public resources in the project The State of the Nation. The development of an innovative instrument for grounding the development of public policies in Romania and offer an overview of the evolution of the Romanian GDP and GDP per capita, the public debt, and the absorption of European funds. The second part of the study consists of quantitative research of Romanian citizens' perception of the economic impact of European integration. In this regard, 
a survey was conducted, in September 2017, on a representative sample of 1107 respondents in order to gather data regarding citizens' evaluation of the state of the Romanian economy and their personal economic performance post-integration as well as their trust in internal and external political actors (political institutions, supranational organization, states, etc.).

\section{Data Presentation and Interpretation}

In the following section, the results of the study will be presented and discussed, starting with the evidence brought by hard data regarding the economic effects of EU integration and continuing with the results of the national omnibus survey.

\subsection{The Economic Effects of EU Integration in Romania: Average Growth, Great Inequalities}

Public data regarding the evolution of Romania's GDP between 1987 and 2015 show that European integration constituted an impulse for the growth of the Romanian GDP, especially compared with its values before 2007. Immediately after the anti-communist revolution, the country's GDP suffered a drop because of the political turbulence and the transition towards the capitalist economy. It took Romania 18 years to recover to a GDP value comparable with the one before the revolution. The peak in terms of GDP was reached in 2008, 1 year after the EU integration $(208,181,626,901$ dollars), but dropped to $167,422,949,529$ dollars in 2009 and has fluctuated ever since. Compared to other Eastern-European countries, the evolution of Romania's GDP in the last 20 years is average. For example, in 1990 Romania's GDP represented 59.1\% of Poland's GDP. This value dropped to $37.3 \%$ in 2015 . These numbers show that Romania has performed rather well economically after EU integration but is still behind CEE countries such as Poland, where the economic benefits of EU integration are more visible. Lastly, Romania's GDP depends on the economic performance of the Bucharest-Ilfov region and there are still great economic cleavages between the urban and the rural areas.

Efforts towards integration have led to a rise in the country's GDP, which might constitute a basis for the utilitarian approach to EU support. This can be explained by the implementation of different regulations negotiated by Romanian politicians as part of the integration agreement as well as by the attraction of new foreign investments as a result of the newly gained international trust generated by integration negotiations. During that time, the media and political discourse in Romania were optimistic towards the integration policies and the positive economic outcome that this process will foster. The Romanian economy became more stable and this can also explain the increase of the GDP. The fluctuations that followed the initial 
enthusiasm of EU integration reflects both the effect of the economic crisis in 2009 and a process of normalization of the Romanian economy and politics, which became business as usual after joining the EU.

When studying how these numbers reflect the economic wellbeing of Romanian citizens compared to citizens from other countries in the Eurozone, one can see that the utilitarian hypothesis of EU support no longer stands. In the last 10 years, Romania has not managed to reduce the disparities with the Eurozone as far as the economic wellbeing of its citizens is concerned. This is especially relevant as Romania's population has dropped considerably in this interval due to migration and low natality. Therefore, even though in absolute terms Romania has seen progress in terms of GDP after the EU integration, this is not reflected in the GDP/capita, which is an important indicator of citizens' economic wellbeing. Compared to other CEE countries, Romania is only above Bulgaria in terms of GDP/capita but has had modest growth in comparison with Slovenia, the Czech Republic, Hungary and Slovakia. Moreover, there are regions in Romania that barely reach $40 \%$ of Bucharest's performance in terms of GDP per capita, while other regions only reach $25 \%$ or $30 \%$ of the economic welfare of the Romanian capital. The gap in terms of GDP/capita between Bucharest and other regions has increased significantly in the last 15 years. The same trend can be observed when analyzing the gap between GDP/capita in urban and rural areas, with the latter being less economically productive. This reveals several cleavages between the Romanian regions and an unequal distribution of the economic wellbeing in the country.

Romania has cultivated a model of economic development based on the growth of the public debt. Compared to other CEE countries, Romania is performing well in terms of public debt, inn third place after Slovenia and Slovakia. However, the weight of the public debt on the GDP tripled during and after the economic crisis. While countries such as the Czech Republic and Bulgaria managed to reduce their public debt, in Romania the value of the debt increases year by year.

In terms of absorption of EU funds, the hard data collected from public sources starting January 2009 until November 2016 show that there is a constant growth of the absorption of European funds, but this growth has been slow-Romania has barely absorbed $45.5 \%$. Moreover, the monthly growth of absorption is unstable, which means that the growth is not constant. On average, the monthly absorption of European funds is $1.06 \%$, with a maximum of $3.6 \%$ reached in January 2016. While this indicator is also correlated with local government performance, the figures show that Romania is not one of the best players when talking about absorption. As a consequence, while some Romanian citizens might directly benefit from the absorption of EU funds, this is not an indicator that might support a positive evaluation of the EU as economic benefits cannot be felt by the majority of the citizens.

We corroborate the hard data analyzed above with the results of the omnibus survey conducted in September 2017 to see if the degree of trust in the EU has changed in the last year, and to what extent economic evaluations contribute to Romanian citizens' Euro-optimism. Still, the hard data analyzed here reflect the media discourse in terms of national government performance and the country's economic performance. Topics such as the lack of impact of economic growth on the 
lives of the regular citizens are largely discussed in the media. This type of discussion in turn can have a great impact on the way Romanians evaluate the EU beyond the economic benefits of integration. Romanians disappointed by their local politicians can look towards the EU as a model of economic organization and political performance. Their support for the Union goes beyond economic calculi and enters the realm of personal preference towards a political system perceived as more effective.

\subsection{Pessimistic Economic Evaluations and Soft Euro-Optimism}

The data collected through the national survey show Romanian citizens have a rather pessimistic view of economic growth following EU integration. Overall, 66.8\% of the participants in the survey stated that Romania is heading in the wrong direction. At the same time, evaluation of life quality is rather low, with approximately $60 \%$ of respondents saying they are rather unsatisfied with the quality of their life. Moreover, 43.2\% of Romanians say their economic situation in 2017 is the same as in the previous year, while $35.8 \%$ say their economic situation worsened. When asked about their predictions for the standard of living in 2018, the respondents had reserved attitudes, with $26 \%$ expecting a better quality of life, $31.3 \%$ saying that their current situation will remain unchanged and $30.5 \%$ expecting a worse year than 2017.

According to the utilitarian approach to EU support, these numbers would suggest that, based on the subjective evaluation of their life quality and economic performance, Romanians are rather unsupportive of the European Union. However, the results of the survey show that $59.4 \%$ of the respondents have a high level of trust in the EU, while $6.7 \%$ say their level of trust in the Union is very high. The only international actor that competes with this level of trust is NATO, with $52.8 \%$ of the respondents saying they have great trust in this organization, while $6.9 \%$ trust it very highly. Compared with trust shown for other internal and external actors (political institutions, economic funds, states)—see Fig. 1, the results show that Romanians tend to trust supranational organizations more than they trust their internal political institutions or the media.

The weak level of trust in the presidency, parliament, government, justice and political parties implies that Romanians are disappointed with the way internal institutions respond to the needs of the citizens. In this sense, the results of the study show a correlation between the disappointment with the internal justice system and a higher level of trust in the EU $(\mathrm{X} 2(30)=388.984, \mathrm{p}<0.1)$. The same correlation is available in the case of a lower level of trust in the presidency (X2 $(25)=232.181, \mathrm{p}<0,1)$, parliament $(\mathrm{X} 2(25)=423.045, \mathrm{p}<0.1)$, government $(\mathrm{X} 2$ $(25)=158.490, \mathrm{p}<0.1)$ and the political parties $(\mathrm{X} 2(25)=381.916, \mathrm{p}<0.1)$. At the same time, a lower trust in Russia as opposed to the EU confirms the results of 


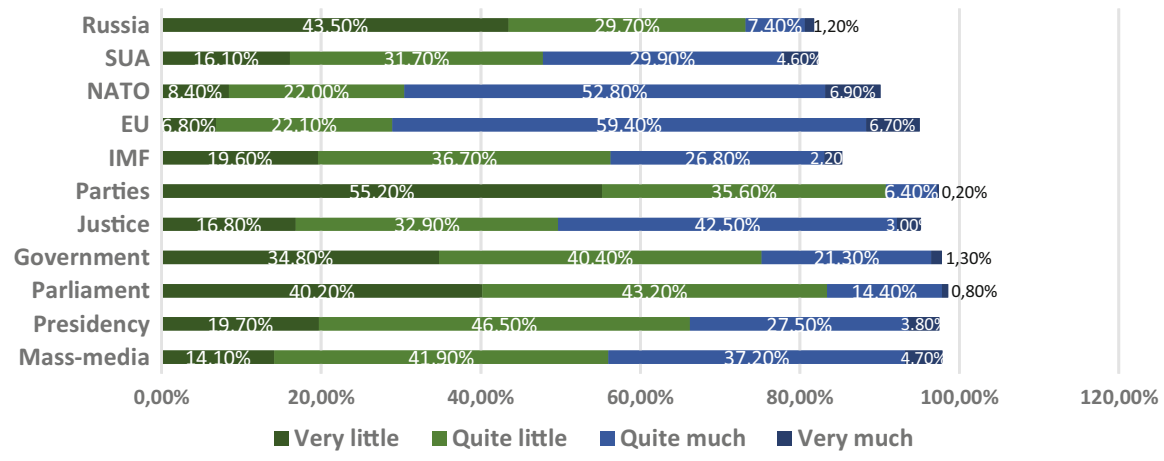

Fig. 1 Level of trust in internal and external actors (political institutions, supranational organizations, economic funds, states)

previous studies (Fomina and Radu 2017) that show that the preference for the EU is "an important geopolitical choice, and an alternative to the Russian hegemony". A possible explanation for these results, which should be further investigated through qualitative research, is that Romanian citizens look up to organizations with strong values and durable strategies, are seen as desirable models against ineffective internal policies and political institutions or threatening geopolitical neighbors.

In line with Romanians' disappointment with internal authorities, the results of the survey show a lower level of satisfaction with Romania's economic growth level, with approximately $77 \%$ of the respondents being rather unsatisfied. When asked to evaluate Romania's economic growth compared to other EU countries or other CEE countries, the respondents are rather pessimistic. For example, $90 \%$ of the respondents assess Romania's economic growth compared to other EU countries as low or very low, while $80 \%$ say that Romania performs poorly from an economical point of view as opposed to other CEE countries such as Poland, the Czech Republic, and Hungary. Overall, approximately $33 \%$ of Romanians consider that the country is performing better economically than it did before the EU integration in 2007, and nearly $40 \%$ consider that the country is underperforming in the same sector.

Results show a correlation between the level of life satisfaction and the evaluation of Romania's economic performance after 2007 (X2(25) = 128.442, p < 0.1) those who evaluate their life satisfaction as higher are more likely to believe that Romania has improved economically since 2007, and those who are less satisfied with their overall quality of life are less inclined to see any progress after EU integration. Still, there is no correlation between EU trust and the area of residence (urban or rural) or the region of residence (Bucharest-Ilfov or other Romanian regions). These results partly confirm the internal cleavages between citizens and NUTS 2 regions, as also revealed by the analysis of hard data regarding the economic effects of EU integration.

Furthermore, when asked if the Romanian government is doing a good job of managing public money, $78.7 \%$ of the respondents assessed the government's 
performance as rather poor. A solution to Romania's poor economic situation can be EU funds (59\% of the respondents consider them highly useful for economic development). However, respondents evaluate the use of these funds as mostly ineffective. This confirms citizens' disenchantment with the local government and a latent utilitarian approach to EU membership. While the EU is seen as a positive model as opposed to the unsatisfactory performance of internal institutions, the Union is as well perceived as a source of economic growth through EU funds. The local authorities' management of such funds, however, is seen as an impediment to economic progress. Still, regardless of Romanians' pessimistic economic self-evaluation, they still maintain trust in the positive economic outcome of EU membership.

\section{Concluding Remarks}

The results of this study show little support for the utilitarian approach to EU support among Romanian citizens, therefore the first hypothesis is validated. In terms of GDP, integration has meant visible growth compared to the interval prior to 2007. However, this is not reflected in the most important indicator of citizens' economic wellbeing-GDP/capita, which is still low in Romania compared to other CEE countries. Even though Romania's economy has made some progress after integration, economic growth at this point is still the result of an increase in public debt rather than from production or investments. At the same time, even though the absorption of EU funds has increased, it is still too low to make a positive impact on economic growth.

The data collected through the national survey is complementary to the results of the secondary data analysis. Romanian citizens view the economic performance of their country pessimistically compared to other EU member states, and state that Romania is heading in the wrong direction. A negative evaluation is also given to personal economic performance, which is expected to either remain the same in 2018 or worsen. When comparing their economic performance to that of other citizens in CEE member states, Romanians state that they are less economically performant. Therefore, the second two hypotheses are confirmed. At the same time, in terms of trust, Romanian citizens tend to trust supranational organizations such as the EU and NATO more than they trust the presidency, parliament, government and internal justice system, confirming thus the fourth hypothesis of our study. The lack of trust in the government can be associated with a lack of satisfaction with its policies and ability to adequately manage the public money. Lastly, the fifth hypothesis of this study was invalidated: while EU funds are seen as a potential source of growth for the Romanian economy, citizens believe that these funds are not used adequately in order to positively impact the country's economy.

Overall, Romanian citizens' evaluation of national and personal economic performances indicates a strong level of pessimism. However, this does not influence the trust Romanians have in the EU. Therefore, the sixth hypothesis of our study is 
invalidated. Trust in the EU cannot be explained through hard predictors, although Romanians' confidence in EU funds contributing to economic growth may indicate a latent utilitarian evaluation of European membership. Given the results of this study, the strong trust Romanians have in the European project can be more accurately explained by soft predictors - a trend that we have named soft euro-optimism. From this point of view, the symbolic meaning of EU membership, which is perceived as desirable compared to other geopolitical options, and the disappointment with internal political institutions are better explanatory factors for the apparent unreserved support Romanians have for the European Union. The results of this study are in line with previous research on the same topic (Fomina and Radu 2017) and could benefit from further qualitative investigation. Still, the trend shown by this study is that in Romania, where EU political issues are still rarely discussed in the public sphere and where trust in the national political institutions and media system is low, the EU continues to keep its aura of desirability for Romanian citizens. This reveals a paradox of Europeanization in the making: the lower the level of information about EU affairs and trust in the local government, the higher the trust in the EU.

\section{References}

Anderson, C. J., \& Kaltenthaler, K. C. (1996). The dynamics of public opinion toward European integration, 1973-93. European Journal of International Relations, 2, 175-199.

Anderson, C. J. (1998). When in doubt, use proxies: Attitudes toward domestic policies and support for European integration. Comparative Political Studies, 31(5), 569-601.

Bârgăoanu, A., Corbu, N., \& Radu, L. (2013). The role of government evaluations and EU identity in shaping economic expectations during the crisis. The case of Romania. European Journal of Science and Theology, 9(4), 225-241.

Boomgaarden, H. G., van Spanje, J., Vliegenthart, R., \& de Vreese, C. H. (2011). Covering the crisis: Media coverage of the economic crisis and citizens' economic expectations. Acta Politica, 46, 353-379.

Bruter, M. (2008). Legitimacy, Euroscepticism \& identity. European Union Journal of Contemporary European Research, 4(4), 273-285.

De Vreese, C. H., Boomgaarden, H. G., \& Semetko, H. (2008). Hard and soft: Public support for Turkish membership in the EU. European Union Politics, 9(4), 511-530.

De Vries, C. (2010). EU issue voting: Asset or liability? European Union Politics, 11(1), 89-117.

De Vries, C., \& Hobolt, S. (2012). When dimensions collide: The electoral success of issue entrepreneurs. European Union Politics, 13(2), 246-268.

De Vries, C., \& Edwards, E. (2009). Taking Europe to its extremes: Extremist parties and public Euroscepticism. Party Politics, 15(1), 5-28.

Eichenberg, R., \& Dalton, R. (1993). Europeans and the European Community: The dynamics of public support for European integration. International Organization, 47(4), 507-534.

Fomina, J., \& Radu, L. (2017). Who's afraid of the "big bad wolf"? A qualitative assessment of Poles' and Romanians' attitudes towards the European Union. In Inquiring communication through qualitative research. Newcastle: Cambridge Scholars Publishing.

Gabel, M. (1998). Public support for European integration: An empirical test of five theories. The Journal of Politics, 60(2), 333-354.

Harteveld, E., van der Meer, T., \& de Vries, C. (2013). In Europe we trust? Exploring three logics of trust in the European Union. European Union Politics, 14(4), 542-565. 
Hooghe, L., \& Marks, G. (2004). Does identity or economic rationality drive public opinion on European integration? Political Science and Politics, 37(3), 415-420.

Hooghe, L., \& Marks, G. (2005). Calculation, community and cues: Public opinion on European integration. European Union Politics, 6(4), 419-443.

Luedtke, A. (2005). A Europe of the regions: Rhetoric or reality? International Studies Review, 7 (1), 101-103.

Rohrschneider, R., \& Whitefield, S. (2016). Responding to growing European Union-skepticism? The stances of political parties toward European integration in Western and Eastern Europe following the financial crisis. European Union Politics, 17(1), 138-161.

Standard Eurobarometer. (2017, August). Accessed November 22, 2017, from http://ec.europa.eu/ commfrontoffice/publicopinion/index.cfm/Survey/getSurveyDetail/instruments/STANDARD/ surveyKy/2142

Van Klingeren, M., Boomgaarden, H. G., \& de Vreese, C. H. (2013). Going soft or staying soft: Have identity factors become more important than economic rationale when explaining Euroscepticism? Journal of European Integration, 35(6), 689-704.

Open Access This chapter is licensed under the terms of the Creative Commons Attribution 4.0 International License (http://creativecommons.org/licenses/by/4.0/), which permits use, sharing, adaptation, distribution and reproduction in any medium or format, as long as you give appropriate credit to the original author(s) and the source, provide a link to the Creative Commons licence and indicate if changes were made.

The images or other third party material in this chapter are included in the chapter's Creative Commons licence, unless indicated otherwise in a credit line to the material. If material is not included in the chapter's Creative Commons licence and your intended use is not permitted by statutory regulation or exceeds the permitted use, you will need to obtain permission directly from the copyright holder. 